\title{
Impact of Macroeconomic Variables on Stock Returns: Evidence from Bombay Stock Exchange (BSE)
}

\author{
Nabila Nisha \\ Department of Accounting and Finance, North South University, Dhaka, Bangladesh
}

Email address:

nabilanisha.nsu@gmail.com

To cite this article:

Nabila Nisha. Impact of Macroeconomic Variables on Stock Returns: Evidence from Bombay Stock Exchange (BSE). Journal of Investment and Management. Vol. 4, No. 5, 2015, pp. 162-170. doi: 10.11648/j.jim.20150405.14

\begin{abstract}
Numerous empirical studies have examined the relationship between macroeconomic variables and stock returns across different stock markets and time horizons by either outlining the influence of only domestic variables or a few global factors. The aim of this paper is to combine both global and domestic factors and extend this presumed relationship between stock returns and macroeconomic variables to the emerging market of India. Using time-series analysis, this paper employs Vector Autoregression (VAR) to determine the impact of macroeconomic variables on the stock returns of Bombay Stock Exchange (BSE). Findings of this paper indicate that a considerable impact of interest rate, gold price, exchange rate and money supply is observed for the stock returns of BSE. Additionally, a strong influence of the global macroeconomic factor of the world price index is also observed, which implies a gradual integration of BSE towards the global financial markets. Finally, the study highlights the managerial and policy implications, future research directions and limitations from the perspective of India.
\end{abstract}

Keywords: Stock Returns, Macroeconomic Variables, Vector Autoregression Model, Bombay Stock Exchange, India

\section{Introduction}

Modern financial theory has increasingly argued that movements in stock prices are highly sensitive to changes in systematic factors and contend upon systematic factors to be sources of risk, such that in the long-run the returns on stocks must reflect the changes in these systematic factors. Since macro changes simultaneously affect many firms' cash flows and may influence the risk-adjusted discount rate, systematic factors are often related to the macroeconomic variables and this implies that a significant relationship can exist between the stock market and the macroeconomic variables of a country.

Numerous empirical studies have investigated this relationship across a number of different stock markets and over a range of different time horizons [1-6]. In fact, studies by $[2,3,7-9]$ provided a strong evidence of a linkage between stock prices and macroeconomic activities. The presence of such evidence has made the relationship between stock returns and macroeconomic variables a subject of increasing interest over the last few decades.

Previous studies like [10-12] assumed that the stock market of a country is totally segmented from other stock markets across the world and hence only domestic macroeconomic variables play a deterministic role in the performance of the stock market of an economy. However, since domestic variables can be influenced by external macroeconomic factors like stock price movements in the global economy, international interest rates that govern capital flows, world oil prices and such others, movements in the global variables can have a gradual impact on the stock returns of the domestic economy. As such, various global macroeconomic factors were hypothesized to impact stock returns by some researchers like [13] and [14] under the assumption that, due to the trend of globalization, stock markets of the most developed economies is perfectly integrated.

A different aspect came into view when [15] cited that a more robust approach to such analysis would be to include both domestic and global factors to determine the impact on the stock returns of an economy. Following this evidence, few studies like [16] and [17] have examined the influence of global macroeconomic variables together with domestic factors on the stock returns. Even then, a void in the literature remains as these studies mostly focused on the developed markets and little on the emerging markets of South Asia. Since emerging markets have volatile prices and supernormal yields, they are less static and partially segmented from the global capital markets. This poses a strong potential that both 
domestic and global macroeconomic variables can impact the stock returns in emerging economies.

This paper thus aims to complement the literature by extending this presumed relationship between stock returns and a set of pre-determined domestic and global macroeconomic variables to the emerging market of India. Evidence for this relationship are drawn in this study through the research methods of Vector Autoregression [VAR] and by applying empirical tests like Johansen cointegration and Vector Error Correction [VEC] estimates. Empirical findings of this research will provide further insights into understanding the underlying macroeconomic factors that can significantly impact the stock returns of a selected Indian stock market. This study can also assist various academicians, researchers, policy makers and particularly the government of the Indian subcontinent to consider the influence of macroeconomic factors when regulating the stock market, its returns and its policies.

\section{Literature Review}

Studies on the linkage between stock returns and macroeconomic variables are motivated by the use of various asset pricing specifications, based on which a number of empirical research has been conducted in both developed and emerging economies across the world. As such, the current study highlights the notable empirical studies in this regard, followed by the research platform of the study and finally, the theoretical background of the proposed constructs has been discussed to determine the gaps for the study.

\subsection{Empirical Studies on Developed Economies}

Renowned studies regarding the relationship between stock returns and macroeconomic variables mostly center on the findings of [1-3, 7, and 18].

[1] documented evidence of a strong positive relationship between NYSE stock returns and macroeconomic factors such as capital expenditures, real rate of return on capital and output during the post-1953 period. Findings from this study also reported consistent evidence of a negative relationship between stock returns and inflation rates. Built on this study, [3] found strong positive correlations are found from this study between the NYSE stock returns and industrial production index, changes in risk premium and yield curve, and expected and unanticipated inflation. Empirical evidence by [2, 7 and 18] additionally complemented these studies by confirming the existence of a linkage between stock returns and macroeconomic variables like dividend yield, default spread and term spread.

Some recent studies that complement these notable findings include [4-6, 8, and 19]. [8] observed a long-run linkage between stock returns and local macroeconomic variables like oil price, money supply and GNP for countries like Canada, Germany, Italy, Japan and US; while, [19] found a significant long-run relationship of stock prices to industrial production, consumer price index and foreign stock prices. [4] indicated that domestic macroeconomic variables of inflation and money supply are significantly related to the stock returns of the NYSE-AMEX-NASDAQ. [5], on the other hand, investigated the S\&P 500 stock price index and claimed a positive relationship of stock prices to money supply, inflation, industrial production, exchange rate, shortterm interest rates and a negative relationship with long-term interest rates. Another study by [6] reported a negative impact of consumer price index and long-term interest rates with US stock returns and of money supply for the Japanese stock returns. However, industrial production index is found to have a significant positive relationship with the stock returns of both the countries in this study.

\subsection{Empirical Studies on Emerging Economies}

Focus of the researchers then shifted to the stock markets of the emerging economies around the world since substantial liberalization and reforms in the political and economic environments in many regions resulted in massive capital inflows and outflows and high profit potential for the emerging markets.

As such, [12] stated industrial production index to have a positive impact, while consumer price index, crude oil price and Treasury Bills to have a significant negative impact on the stock returns of Malaysia. A cross-sectional study by [20] claimed that global macroeconomic factor of the world market return and domestic macroeconomic variables of exchange rate and interest rate have a significant impact on the stock returns of Turkey. [9] then contributed to these findings by providing evidence of a positive impact of money supply and a negative impact of interest rate, industrial production index, oil price and foreign exchange rate on the Turkish stock returns. Conversely, [21] revealed a negative impact of consumer price index and a positive impact of industrial production index, exchange rate and money supply on the Pakistan stock prices.

Empirical studies conducted on the Indian stock market include the comparable time-series works of [22-25]. [22] observed an impact of industrial production index and inflation, but it reports no association of stock returns with exchange rate, money supply and gold prices. A recent timeseries study conducted by [23] examined the impact of macroeconomic variables like industrial production index, exports, foreign direct investment, money supply, interest rate and exchange rate on the Indian stock returns. Their findings support a considerable influence of only interest rates on the stock returns of India. On the other hand, [24] claimed industrial production index to be the only significant macroeconomic variable for the Indian stock prices. [25] also supported the literature by conducting a time-series analysis upon the macroeconomic factors of industrial production, exchange rate and wholesale price index over the period 1995-2009.

\subsection{Research Setting of the Study}

An interesting strand of literature was conducted by [15$17,26]$. These studies examined the influence of a set of global macroeconomic factors or a combination of both 
domestic and global macroeconomic variables for the emerging economies. [15] observed the influence of global macroeconomic variables like world stock market return, the return on a foreign exchange index, oil prices, world industrial production and the world inflation rate for 20 emerging economies over 1976-92. However, findings of this study reported these factors to be insufficient to characterize the stock returns of the emerging economies. [16] then studied 20 emerging markets over a period of 1985-97 and their findings suggest that factors like price-toearnings, dividend yield, real activity, inflation, exchange rate, money supply and world market returns are most significant for the stock returns of majority of these economies.

On the other hand, [17] studied six Asian countries of Indonesia, Korea, Malaysia, Philippines, Singapore and Thailand along with Mexico with regard to the 1997 crisis and reported that global risk factors are more influential in explaining stock returns, although a significant impact of local factors like consumer price index, industrial production, exchange rate and risk-free rate is claimed by their study as well. [26] further examined the four emerging economies of Brazil, Russia, India and China [BRIC] over the period of 1999-2006, but reported no significant association of the stock prices of these emerging countries with exchange rates and oil prices.

Future research directions of many such previous studies claim that there is still scope to examine the impact of macroeconomic variables, particularly the global macroeconomic factors, upon the stock returns. Specifically, the focus needs to be bestowed more upon the emerging economies since the economic environment of these countries are continually changing in recent times.

\subsection{Proposed Constructs of the Study}

For a comprehensive analysis of the impact of macroeconomic variables on stock returns, selection of the stock markets should be such that it accounts for majority of the stock trading across the country. Hence, the major stock market of Bombay Stock Exchange Limited [BSE] has been selected for analysis in this study. Stock returns of these major stock markets are represented through the general stock price index of these markets, which is why the BSE SENSEX has been selected for India. BSE SENSEX includes the largest and most actively traded stocks of 30 wellestablished and financially sound companies listed on Bombay Stock Exchange and represents various industrial sectors of the Indian economy.

In order to explain the variations in the stock returns of BSE, macroeconomic variables has been selected for this study in such a way that it complements the interrelationships between the goods market, money market and the capital market on a broad perspective. Hence, the following six domestic macroeconomic variables along with a global macroeconomic factor are selected in light of the literature and availability of data for the purpose of analysis.

\subsection{Industrial Production Index}

This variable is used as a proxy to measure the sustained domestic industrial growth of India. Since increase in the production of the industrial sector can lead to more profits and high dividends for the industries, its influence on the expected future cash flows can increase stock prices. Hence a positive relationship of the industrial production index with stock prices is expected. As such, the findings of [3, 5-6, 21] support this claim and so this variable is considered to be a significant factor to explain the variations in stock returns in this study.

\subsection{Consumer Price Index}

This variable measures the average change in prices of domestic goods and services during a specific period and is used in this dissertation as a proxy for the inflation rate of India. Inflation rate is a money market variable and is often related to nominal interest rates and any increase in the nominal interest rates can raise discount rates, which in turn can negatively influence the cash flows and hence stock prices. As such, a negative impact of inflation upon the stock prices is expected. Since [1] and [6] also supports this claim, this variable has been selected for analysis in this study.

\subsection{Money Supply}

The variable of broad money signifies the domestic money market and is used as a proxy for money supply of India in this study. Broad money includes the currency outside banks, demand deposits, time deposits and the deposits of other financial institutions in the central bank. Money supply has a two-fold impact on stock prices. As supported by [6], an increase in money supply can raise inflation and lower stock prices, thus indicating a negative impact. However, as claimed by [5] and [21], an increase in money supply can increase earnings and cash flows as well, thereby indicating a positive impact. Since this variable provides mixed evidence of their impact upon stock prices, it has been used for analysis in this study.

\subsection{Interest Rates}

The short-term bank deposit rate represents the domestic money market and is used as a proxy for the interest rate of India. It is paid to the depositor when cash is deposited in the bank and any increase in this rate will increase the opportunity cost of holding money, because the preference to hold money at banks at a high rate will be more favored than investments in stocks. As such, a negative relationship is expected between interest rates and stock prices and since this claim is further supported by [9, 20, and 27], this variable has been selected for analysis.

\subsection{Exchange Rates}

Exchange rate is the rate at which one currency can be exchanged for another currency and due to the dominance 
of US dollar in international transactions, exchange rate between India [Rupee] against the US [Dollar] has been used in this study. The impact of exchange rate on stock prices is likely to vary from an export-oriented to an import-oriented country. As evidenced by [27], any depreciation against the US dollar in an import-oriented country results in a negative impact on stock prices since an increase in the volume of imports leads to lower cash flows for the domestic industries and a subsequent fall in stock prices. Alternatively, [5] and [21] claimed that depreciation against the US dollar in an export-oriented country leads to a positive impact on stock prices because an increase in the volume of exports leads to higher cash flows for the domestic industries followed by a rise in stock prices. Since this variable indicates a two-fold impact upon stock prices, it has been selected for this study.

\subsection{Gold Price}

Gold represents the money market and is considered to be a better and safe investment than stocks, since gold can be used as a hedge against inflation and is often an alternative investment when there is idle money in hold. An increase in gold price can thus reduce the level of investment in stocks and lower stock prices and so a negative relationship is expected between stock prices and gold price. However, no significant relationship between stock prices and gold price is claimed by [9] and [22]. This indicates a scope for further research and hence this variable has been selected for analysis.

\subsection{World Price Index}

MSCI World Index signifies a value-weighted world price index and is used as a proxy for the global macroeconomic variable in this study. It is a common benchmark index of over 6000 global stocks, representing only the developed economies of the world like Australia, France, Germany, Italy, Japan, New Zealand, Norway, Singapore, Spain, United Kingdom, United States and such others. As such, due to the trend of globalization and consequent integration with the developed economies, a positive impact of the world price index is expected upon the stock prices. Since this claim is further supported by [14-16], this variable has been selected for this study.

\section{Methodology and Data}

\subsection{Research Method}

In order to capture the dynamic links between stock returns and macroeconomic variables, an advanced estimation technique of Vector Autoregression [VAR] models has been used in this study. VAR is commonly used for forecasting systems of interrelated time series and for analyzing the dynamic impact of random disturbances on the system of variables. This has become a well-established methodology since it takes into account the long-term relationship between the specified factors and can also help to capture any short-run dynamics that might exist between the variables of the model. The use of VAR models can be found in notable studies like [6, 8, and 19]. As such, this study applies a general VAR model to examine the impact of macroeconomic variables upon the stock returns of BSE.

\subsection{Model}

Following [3], a pre-specified multi-factor APT model has been developed for this study and the generic model takes the form as given below.

$$
\begin{gathered}
S P I_{t}=\alpha+\beta_{1} * I P I_{t}+\beta_{2} * C P I_{t}+\beta_{3} * M S_{t}+\beta_{4} * I R_{t}+ \\
\beta_{5} * E R_{t}+\beta_{6} * G P_{t}+\gamma * W P I_{t}+\varepsilon_{t} \\
\text { Table 1. Model Specifications }
\end{gathered}
$$

\begin{tabular}{ll}
\hline where, & $\mathrm{SPI}_{\mathrm{t}}=$ stock price index for month $\mathrm{t}$ \\
$\mathrm{IPI}_{\mathrm{t}}=$ industrial production index for month $\mathrm{t}$ \\
$\mathrm{CPI}_{\mathrm{t}}=$ consumer price index for month $\mathrm{t}$ \\
$\mathrm{MS}_{\mathrm{t}}=$ money supply for month $\mathrm{t}$ \\
$\mathrm{IR}_{\mathrm{t}}=$ interest rate for month $\mathrm{t}$ \\
$\mathrm{ER}_{\mathrm{t}}=$ exchange rate for month $\mathrm{t}$ \\
$\mathrm{GP}_{\mathrm{t}}=$ gold price for month $\mathrm{t}$ \\
$\mathrm{WPI}_{\mathrm{t}}=$ world price index for month $\mathrm{t}$ \\
$\varepsilon_{\mathrm{t}}=$ error term of the regression for month $\mathrm{t}$ \\
\hline
\end{tabular}

Before applying this model to the data sets of India, raw data for the stock price index and the macroeconomic variables are transformed into natural logs. This conversion has been supported in the literature by [3] and in recent times by [20], since the variables converted into natural logs can be interpreted as growth rates on their first difference and as long-term elasticity for their coefficients in the cointegrating vector. As such, the first logarithmic difference of the macroeconomic variables and the stock price index has been used in this model across the same time period to study the case of India in this study.

\subsection{Data Sources}

To examine the impact of macroeconomic variables upon the stock returns, monthly data series covering a period of 15 years from January 2000 till December 2015 has been analyzed using the statistical package of EViews 8.1 in this study. Data for all the variables is collected from DataStream 5.0, except for money supply and consumer price index, which has been gathered from the database of the Reserve Bank of India [RBI].

\section{Data Analysis and Results}

\subsection{Stationarity Checks}

To conduct a time-series analysis, it is important to determine the stationarity of the data series because if a linear combination of the variables is stationary and integrated of the same order, it indicates that a long-term relationship can exist between the variables of a data series. With this expectation, unit root tests are conducted for the data series of this study. The results for the unit root tests of Augmented Dickey-Fuller [ADF] and Ng-Perron [NP] are 
given below.

Table 2. Unit Root \& Stationarity Tests.

\begin{tabular}{|c|c|c|c|c|}
\hline \multirow{3}{*}{ Variables } & \multicolumn{2}{|c|}{ Null Hypothesis: variable is non-stationary } & \multicolumn{2}{|c|}{ Null Hypothesis: variable is non-stationary } \\
\hline & \multicolumn{2}{|c|}{ Augmented Dickey-Fuller [ADF] test statistic } & \multicolumn{2}{|c|}{ Ng-Perron [NP] test statistic } \\
\hline & Level & First Difference & Level & First Difference \\
\hline SPI & -0.19 & $-10.03 * * *$ & -0.34 & $-10.07 * * *$ \\
\hline IPI & 1.17 & -0.75 & 0.83 & $-27.95 * * *$ \\
\hline CPI & -1.14 & $-10.74 * * *$ & -1.14 & $-10.74 * * *$ \\
\hline MS & 1.52 & -1.88 & 1.27 & $-10.32 * * *$ \\
\hline IR & -0.99 & $-5.66^{* * *}$ & -1.34 & $-10.26 * * *$ \\
\hline ER & -1.73 & $-9.08 * * *$ & -2.10 & $-9.07 * * *$ \\
\hline GP & 0.66 & $-12.64 * * *$ & 0.78 & $-12.53 * * *$ \\
\hline WPI & -1.68 & $-10.10^{* * *}$ & -1.96 & $-10.21 * * *$ \\
\hline $1 \%$ level & -3.49 & & -3.49 & \\
\hline $5 \%$ level & -2.89 & & -2.89 & \\
\hline $10 \%$ level & -2.58 & & -2.58 & \\
\hline
\end{tabular}

$* * *$ implies significance at $1 \%$ level; ** implies significance at $5 \%$ level; *implies significance at $10 \%$ level

Table 1 indicates that the null hypothesis of nonstationarity for the data series of India cannot be rejected at any significance level under the ADF test. In case of first difference of these variables, the null hypothesis of nonstationarity is rejected by the ADF test at $1 \%$ significance level for all the variables, except the industrial production index [IPI] and money supply [MS]. This implies that these two variables has two unit roots and hence to make them integrated of order 1, they are differenced a second time. As such, the variables of industrial production index [IPI] and money supply [MS] will be considered to be lagged by one period for any further analysis of India under this study. For more robust results, NP unit root test was also conducted with an improved finite sample but the results indicate that the null hypothesis of non-stationarity for the data series of India cannot be rejected in level, but all the variables are rejected at $1 \%$ significance level in their first difference. NP test results thereby correspond to the ADF test results derived for India in this study.

\subsection{Johansen Cointegration Test}

To investigate the presence of a long-run equilibrium relationship between the stock price index and the macroeconomic variables, the Johansen cointegration test is used in this study following [28]. This method applies the maximum likelihood technique to a VAR model to determine the presence of cointegrating vectors in a non-stationary time series through two likelihood ratio tests of trace test and maximum eigenvalue test. Thus, if two variables are found cointegrated, it implies some relationship in the long-run and a restricted divergence from the long-run equilibrium path for the variables. For this study, the cointegration test is applied with 3 lags of the variables on the basis of Akaike Information Criteria [AIC] and its general representation has been derived from the VAR model.
Table 3. Trace Test

\begin{tabular}{llll}
\hline Null Hypothesis & Trace statistic & $\mathbf{5 \%}$ Critical value & Probability \\
\hline $\mathrm{r}=0^{*}$ & 251.84 & 159.53 & $0.00^{*}$ \\
$\mathrm{r} \leq 1^{*}$ & 168.94 & 125.62 & $0.00^{*}$ \\
$\mathrm{r} \leq 2^{*}$ & 108.50 & 95.75 & $0.01^{*}$ \\
$\mathrm{r} \leq 3$ & 67.51 & 69.82 & 0.08 \\
$\mathrm{r} \leq 4$ & 30.16 & 47.86 & 0.71 \\
$\mathrm{r} \leq 5$ & 16.19 & 29.80 & 0.70 \\
$\mathrm{r} \leq 6$ & 5.63 & 15.49 & 0.74 \\
$\mathrm{r} \leq 7$ & 0.06 & 3.84 & 0.80 \\
\hline
\end{tabular}

*denotes rejection of the hypothesis at the 0.05 level

Trace test indicates 3 cointegrating equations at the 0.05 level

Table 4. Maximum Eigenvalue Test.

\begin{tabular}{llll}
\hline Null Hypothesis & Max-Eigen statistic & 5\% Critical value & Probability \\
\hline $\mathrm{r}=0^{*}$ & 82.89 & 52.36 & $0.00^{*}$ \\
$\mathrm{r} \leq 1^{*}$ & 60.44 & 46.23 & $0.00^{*}$ \\
$\mathrm{r} \leq 2^{*}$ & 40.99 & 40.08 & $0.04^{*}$ \\
$\mathrm{r} \leq 3^{*}$ & 37.35 & 33.88 & $0.02^{*}$ \\
$\mathrm{r} \leq 4$ & 13.97 & 27.58 & 0.83 \\
$\mathrm{r} \leq 5$ & 10.56 & 21.13 & 0.69 \\
$\mathrm{r} \leq 6$ & 5.57 & 14.26 & 0.67 \\
$\mathrm{r} \leq 7$ & 0.06 & 3.84 & 0.80 \\
\hline
\end{tabular}

*denotes rejection of the hypothesis at the 0.05 level

Max-Eigen value test indicates 4 cointegrating equations at the 0.05 level

Table 2 indicates the rejection of the null hypothesis of no cointegrating vector, at most one cointegrating vector and at most two cointegrating vectors at 5\% significance level under the Trace test. Although this implies the presence of three cointegrating relationships among the variables used for India in this study, results of the Maximum Eigenvalue test from Table 3 rejects at most three cointegrating vectors at 5\% significance level. In case of conflicting results, the Maximum Eigenvalue test is typically considered and so four cointegrating relationships 
among the stock price index and the macroeconomic variables will tend to prevail for India.

Table 5. Normalized Cointegrating Coefficients.

\begin{tabular}{lllll}
\hline Variables & Coefficient & Std. Error & t-statistic & p-value \\
\hline SPI & 1.00 & - & - & - \\
IPI & -0.04 & 1.05 & -0.03 & 0.531 \\
CPI & -0.06 & 0.05 & -1.15 & 0.660 \\
MS & -9.01 & 2.63 & -3.43 & 0.892 \\
IR & 0.55 & 0.09 & $5.89^{*}$ & 0.032 \\
ER & -1.14 & 0.39 & -2.91 & 0.583 \\
GP & -1.15 & 0.07 & -17.74 & 0.990 \\
WPI & -2.11 & 0.15 & -13.74 & 0.982 \\
Constant & 19.96 & - & - & - \\
\hline
\end{tabular}

Critical value at $5 \%$ level of significance with 1 degree of freedom for the chi-square distribution: 3.84

*denotes rejection of the hypothesis at the 0.05 level

By using the estimated values of the coefficients in the cointegrating vector from Table 4, the long-run relationship between the stock price index and the macroeconomic variables has been modeled for India as given below.

$$
\begin{aligned}
& S P I=19.96-0.04 * I P I-0.06 * C P I-9.01 * M S+ \\
& 0.55 * I R-1.14 * E R-1.15 * G P-2.11 * W P I
\end{aligned}
$$

Results indicate that industrial production index [IPI], consumer price index [CPI], money supply [MS], exchange rates [ER], gold price [GP] and the world price index [WPI] in the estimated equation has a negative relationship with the stock price index [SPI] of India in the long-run. However, all these variables exhibit insignificant relationship while only the variable of interest rates [IR] is observed to have a positive and significant impact upon the stock price index [SPI], which means, in the long-run interest rates [IR] will have a considerable influence upon the stock price index [SPI] of India.

\subsection{Vector Error Correction [VEC] Estimates}

Following the presence of cointegrating relationships between the stock price index and macroeconomic variables, a restricted Vector Autoregression [VAR] in the form of Vector Error Correction [VEC] model is estimated for India. Estimates of the VEC model attempts to capture the long-run causality and the short-run dynamics between the stock returns and its own lags, along with the lags of the macroeconomic variables. It restricts the long-run behavior of the variables to converge to their cointegrating relationships by gradually correcting the deviation of the variables through the error correction term, which is the residual series of the cointegrating vectors normalized under the Johansen cointegration procedure. Following this characteristic, on the basis of Akaike Information Criteria [AIC] the VEC model has been re-parameterized from the VAR process by using 3 lags of the variables and is given below.
Table 6. Vector Error Correction Estimates.

\begin{tabular}{lllll}
\hline Variables & Coefficient & Std. Error & t-statistic & p-value \\
\hline Error correction term & -0.17 & 0.07 & $-2.58^{* *}$ & 0.09 \\
D[SPI[-1]] & 0.00 & 0.12 & 0.02 & 0.80 \\
D[SPI[-2]] & 0.14 & 0.11 & 1.28 & 0.71 \\
D[SPI[-3]] & 0.21 & 0.09 & 2.27 & 0.77 \\
D[IPI[-1]] & 0.20 & 0.17 & 1.22 & 0.68 \\
D[IPI[-2]] & 0.42 & 0.24 & 1.74 & 0.70 \\
D[IPI[-3]] & 0.24 & 0.15 & 1.53 & 0.62 \\
D[CPI[-1]] & 0.01 & 0.05 & 0.13 & 0.84 \\
D[CPI[-2]] & -0.01 & 0.05 & -0.15 & 0.87 \\
D[CPI[-3]] & -0.09 & 0.05 & -1.78 & 0.69 \\
D[MS[-1]] & -1.46 & 0.63 & -2.32 & 0.98 \\
D[MS[-2]] & -0.77 & 0.62 & -1.23 & 0.86 \\
D[MS[-3]] & 0.48 & 0.53 & 0.90 & 0.75 \\
D[IR[-1]] & 0.05 & 0.24 & 0.22 & 0.72 \\
D[IR[-2]] & -0.49 & 0.23 & -2.07 & 0.88 \\
D[IR[-3]] & -0.68 & 0.25 & -2.68 & 0.85 \\
D[ER[-1]] & -0.39 & 0.47 & -0.84 & 0.59 \\
D[ER[-2]] & -0.17 & 0.48 & -0.35 & 0.54 \\
D[ER[-3]] & 1.19 & 0.47 & 2.55 & 0.93 \\
D[GP[-1]] & 0.09 & 0.16 & 0.55 & 0.50 \\
D[GP[-2]] & -0.11 & 0.16 & -0.64 & 0.61 \\
D[GP[-3]] & -0.06 & 0.16 & -0.38 & 0.74 \\
D[WPI[-1]] & 0.73 & 0.16 & $4.43 *$ & 0.04 \\
D[WPI[-2]] & -0.15 & 0.18 & -0.79 & 0.76 \\
D[WPI[-3]] & -0.29 & 0.17 & -1.72 & 0.84 \\
Constant & 0.01 & 0.01 & 0.82 & 0.99 \\
R-squared & 0.60 & & & \\
Adjusted R-squared & 0.49 & & & \\
Residual Sum of Squares & 0.39 & & & \\
F-statistic & 5.36 & & & \\
\hline
\end{tabular}

Critical value at $5 \%$ level of significance with 1 degree of freedom for the chi-square distribution: 3.84

*denotes rejection of the hypothesis at the 0.05 level

$* *$ denotes rejection of the hypothesis at the 0.1 level

By considering a lag of one period for industrial production index [IPI] and money supply [MS] in order to hold stationarity, estimated coefficients of the macroeconomic variables and the stock price index are used from Table 5 to form the following Vector Error Correction [VEC] model for India.

$$
\begin{array}{r}
\Delta S P I_{t}=0.01+0.00 \Delta S P I_{t-1}+0.14 \Delta S P I_{t-2}+0.21 \Delta S P I_{t-3} \\
+0.20 \Delta I P I_{t-2}+0.42 \Delta I P I_{t-3}+0.24 \Delta I P I_{t-4}+0.01 \Delta C P I_{t-1} \\
-0.01 \Delta C P I_{t-2}-0.09 \Delta C P I_{t-3}-1.46 \Delta M S_{t-2}-0.77 \Delta M S_{t-3} \\
+0.48 \Delta M S_{t-4}+0.05 \Delta I R_{t-1}-0.49 \Delta I R_{t-2}-0.68 \Delta I R_{t-3}- \\
0.39 \Delta E R_{t-1}-0.17 \Delta E R_{t-2}+1.19 \Delta E R_{t-3}+0.09 \Delta G P_{t-1}- \\
0.11 \Delta G P_{t-2}-0.06 \Delta G P_{t-3}+0.73 \Delta W P I_{t-1}-0.15 \Delta W P I_{t-2} \\
-0.29 \Delta W P I_{t-3}-0.17 \mu_{t-1}+\mathrm{e}_{t}(3)
\end{array}
$$

The error correction term $\left[\mu_{t-1}\right]$ here poses a negative sign as expected but is insignificant in the long-run at $5 \%$ significance level, implying that the stock price index [SPI] of India may not adjust to long-run equilibrium and disequilibrium may persist for a long time. That is, there is no evidence of cointegration. However, if the error correction term is analyzed at a less stringent level, then it is found significant at $10 \%$ level of significance. This indicates that there is some possibility of cointegration existing for the stock price index [SPI] of India. Results further indicate only a consistent positive relationship of lagged stock price index 
[SPI] and industrial production index [IPI] to the stock price index [SPI] of India. While no constant negative relationship is observed, none of the variables exhibit any significant relationship with the stock price index [SPI] of India, except for the first lag of the world price index [WPI]. Partial presence of a long-run causal relationship with the macroeconomic factors thus delays the convergence of the stock price index to the equilibrium. The value of $\mathrm{R}$-squared $\left[R^{2}\right]$ further indicates that the model provides a good fit to the data since the lagged values of the macroeconomic variables explains about $60 \%$ of the lags in the stock price index of India. The low value of the minimized residual sum of squares [0.39] and the value of adjusted R-squared $\left[\overline{\mathrm{R}}^{2}\right]$ [49\%] also confirms this result for India.

After the VEC model is estimated, a number of diagnosis tests are conducted to ensure that there are no problems of autocorrelation, heteroskedasticity and the model is well specified. For this purpose, Breusch-Godfrey Serial Correlation LM Test, White Test of Heteroskedasticity and Ramsey's Reset Test has been undertaken in this study. Table 6 provides the results of the diagnosis tests.

Table 7. Diagnosis Tests.

\begin{tabular}{ll}
\hline Breusch-Godfrey Serial Correlation LM Test & \\
\hline F-statistic & 0.013 \\
p-value & $(0.909)$ \\
Durbin-Watson statistic & 2.103 \\
( ${ }^{\text {st }}$ order of autocorrelation) & \\
F-statistic & 0.661 \\
p-value & $(0.784)$ \\
Durbin-Watson statistic & 2.116 \\
(12 ${ }^{\text {h }}$ order of autocorrelation) & \\
Heteroskedasticity Test: White & \\
F-statistic & 0.502 \\
p-value & $(0.806)$ \\
Observations*R-squared & 3.118 \\
p-value & $(0.794)$ \\
Durbin-Watson statistic & 2.175 \\
$p$-values are reported in parentheses & \\
degrees of freedom for F-distribution is $(6,172)$ & \\
degrees of freedom for chi-square distribution is (6) & \\
Ramsey's RESET Test & \\
F-statistic & 1.603 \\
p-value & $(0.207)$ \\
Durbin-Watson statistic & 2.090 \\
$p$-values are reported in parentheses & \\
degrees of freedom for F-distribution is (6,172) & \\
\hline
\end{tabular}

*denotes rejection of the hypothesis at the 0.05 level

Durbin-Watson significance table reported a critical lower bound value (1.634) and an upper bound value (1.715) at 5\% significance level [29]. The observed test statistic (2.103) is greater than the tabulated lower and upper bounds, which indicates that the null hypothesis cannot be rejected at $5 \%$ significance level. Therefore, the 1st order of autocorrelation between residuals is found zero for the estimated VEC model For further analysis, the 12th order of autocorrelation is also checked for the model. The p-value of F-distribution is greater than 0.05 whereas the observed F-statistic is less than the critical value (1.834) from the F-distribution table [30].
Hence, the null hypothesis cannot be rejected at $5 \%$ significance level. Even the Durbin-Watson test statistic (2.116) is greater than the tabulated lower and upper bounds, which indicates that the null hypothesis cannot be rejected at $5 \%$ significance level. Therefore, the errors of the estimated VEC model have zero autocorrelation.

The $\mathrm{p}$-value of F-distribution is more than 0.05 whereas the observed F-statistic is less than the critical value (2.175) from F-distribution table [30]. Hence, the null hypothesis cannot be rejected at 5\% significance level. Next, p-value of the LM-statistic is more than 0.05 and the value of $n^{*} \mathrm{R}^{2}$ (3.118) is smaller than the critical value (12.59) from chisquare distribution table [30]. Therefore, again the null hypothesis cannot be rejected at 5\% significance level. As such, there is no heteroskedasticity in the VEC model which means constant variance exists for the estimates done for this study.

To examine for the general misspecification of the VEC model, the p-value of F-distribution for the Ramsey's RESET test is observed. Following the F-distribution table [30], the observed F-statistic is less than the critical value (2.175) and the $p$-value is also more than 0.05 . Hence, the null hypothesis cannot be rejected at 5\% significance level. This means that the VEC model estimated in this study is of correct specification.

\section{Findings and Implications}

Findings of this study report some consistency with the notable findings of [23]. This partial consistency arises since the two samples share a common period of 8 years between them and some macroeconomic variables as well. Over a sample period of 1995-2007, [23] applied the Johansen cointegration analysis and a number of other empirical tests to examine the impact of industrial production index, exports, foreign direct investment, money supply, interest rate and exchange rate on the stock returns of India. Through cointegration analysis, [23] stated the significance of industrial production index and money supply upon the stock returns, while findings of this study claim only interest rates to have a significant positive impact for India.

Following the VEC model, no long-run causal relationship is observed between the lags of domestic macroeconomic variables and the stock price index of India, implying the absence of short-run dynamic adjustments to the long-run equilibrium of the stock price index. However, the global macroeconomic variable of the world price index exhibits a significant positive relationship with the stock price index of India, indicating a partial presence of a long-run causal relationship with the global macroeconomic factor for BSE. To sum up, the global macroeconomic factor of the world price index plays a deterministic role for the stock returns of India, followed by a considerable impact of the domestic variables of interest rate, gold price, exchange rate and money supply - in the order of influencing strength.

Empirical findings from the time-series and cross-sectional analysis of this study thus imply that a time-variation in the 
risk exposure arises from the changes in the domestic macroeconomic variables of India and do not conforms timely to the stock prices of BSE. Findings further claim that BSE is gradually moving towards integration with the global capital markets. However, significant time-variation in the risk exposures from the changes in the domestic macroeconomic variables cannot be completely ignored for India.

Results of this study thereby indicate important implications for both researchers and practitioners. From a research point of view, the need to develop a model that can address a gradual integration towards the global financial markets is stressed, particularly for emerging economies like India. From a practical point of view, the revelation of a relationship between macroeconomic factors and stock returns can enable investors of India to adopt better diversification strategies and risk-return trade-offs by considering the influence of external shocks as well as the domestic factors. Policymakers and regulators of India must therefore strictly monitor the dissemination of information and the time-varying risk exposures that can arise from the changes in the domestic macroeconomic factors. Special care must also be taken to monitor the changes in the global macroeconomic factors like the world price index, in order to avoid any unnecessary consequences for the Indian stock market following any adverse changes in the global factors.

\section{Limitations and Future Research Directions}

The implications of this study, however, are not farreaching since this study also has some limitations. To begin with, the selection of macroeconomic variables used in this study is arbitrary and the set of variables are not exhaustive. Use of some other domestic and global macroeconomic variables may have given a better insight to the findings of this analysis. Furthermore, the research methodologies used in this study are known to be sensitive to the choice of lags and as a result, findings may be somewhat inconsistent with previous empirical evidences. Finally, unavailability of data and time constraints has deterred the employment of a longer period of data in this study as well as using a different frequency of data like weekly or daily data series for the set of variables. Future research directions can be related to the use of varied global macroeconomic factors like international interest rates, global inflation and world oil prices to examine the influence upon the stock returns of the Indian stock market.

\section{References}

[1] Fama, E.F. [1981]. Stock returns, real activity, inflation and money. The American Economic Review, 71, 4, 545-565. Retrieved from http://www.jstor.org/stable/1806180

[2] Fama, E.F. [1990]. Stock returns, expected returns, and real activity. The Journal of Finance, 45, 4, 1089-1108. Retrieved from http://www.jstor.org/stable/2328716

[3] Chen, N., Roll, R. and Ross, S.A. [1986]. Economic forces and the stock market. The Journal of Business, 59, 3, 383-403. Retrieved from http://www.jstor.org/stable/2352710

[4] Flannery, M.J. and Protopapadakis, A.A. [2002]. Macroeconomic factors do influence aggregate stock returns. The Review of Financial Studies, 15, 3, 751-782. Retrieved from http://www.jstor.org/stable/2696720

[5] Ratanapakorn, O. and Sharma, S.C. [2007]. Dynamic analysis between the US stock returns and the macroeconomic variables. Applied Financial Economics, 17, 5, 369-377.

[6] Humpe, A. and Macmillan, P. [2009]. Can macroeconomic variables explain long-term stock market movements? A comparison of the US and Japan. Applied Financial Economics, 19, 2, 111-119.

[7] Schwert, G.W. [1990]. Stock returns and real activity: a century of evidence. The Journal of Finance, 45, 1237-1257.

[8] Cheung, Y. and Ng, L.K. [1998]. International evidence on the stock market and aggregate economic activity. Journal of Empirical Finance, 5, 3, 281-296. Retrieved from http://www.sciencedirect.com/science/article/pii/S092753989 $700025 \mathrm{X}$

[9] Buyuksalvarci, A. [2010]. The effects of macroeconomics variables on stock returns: Evidence from Turkey. European Journal of Social Sciences, 14, 3, 404-416. Retrieved from http://www.eurojournals.com/ejss_14_3_06.pdf

[10] Kwon, C.S. and Shin, T.S. [1999]. Cointegration and causality between macroeconomic variables and stock market returns. Global Finance Journal, 10, 1, 71-81. Retrieved from http://www.sciencedirect.com/science/article/pii/S104402839 900006X

[11] Ibrahim, M.H. and Aziz, H. [2003]. Macroeconomic Variables and the Malaysian equity market: A view through rolling subsamples. Journal of Economic Studies, 30, 1, 6-27.

[12] Tan, B.C., Loh, W.L. and Zainudin, A. [2006]. Dynamics Between Stock Price, Oil Price And Macroeconomic Activities: A VAR And Impulse Response Approach. Proceedings of the 2nd IMT-GT Regional Conference on Mathematics, Statistics and Applications, University of Science Malaysia, pp. 167-179.

[13] Brown, S.J. and Otsuki, T. [1993]. Risk premia in PacificBasin capital markets. Pacific-Basin Finance Journal, 1, 3, 235-261. Retrieved from http://www.sciencedirect.com/science/article/pii/0927538X93 90025D

[14] Buckberg, E. [1995]. Emerging stock markets and international asset pricing. The World Bank Economic Review, $9,1,51-74$

[15] Harvey, C.R. [1995]. Predictable risk and returns in emerging markets. The Review of Financial Studies, 8, 3, 773-816. Retrieved from http://www.jstor.org/stable/2962239

[16] Bilson, C.M., Brailsford, T.J. and Hooper, V.J. [2001]. Selecting macroeconomic variables as explanatory factors of emerging stock market returns. Pacific-Basin Finance Journal, 9, 4, 401-426. Retrieved from http://ssrn.com/abstract $=201908$ 
[17] Lint, C.R. [2002]. Risk profiles: how do they change when stock markets collapse?. Journal of International Financial Markets, 12, 1, 59-80. Retrieved from http://www.sciencedirect.com/science/article/pii/S104244310 1000488

[18] Fama, E.F. and French, K.R. [1989]. Business conditions and expected returns on stocks and bonds. Journal of Financial Economics, 25, 1, 23-49. Retrieved from http://www.sciencedirect.com/science/article/pii/0304405X89 900950

[19] Nasseh, A. and Strauss, J. [2000]. Stock prices and domestic and international macroeconomic activity: a cointegration approach. The Quarterly Review of Economics and Finance, 40, 2, 229-245. Retrieved from http://www.sciencedirect.com/science/article/pii/S106297699 900054X

[20] Kandir, S.Y. [2008]. Macroeconomic variables, firm characteristics and stock returns: Evidence from Turkey. International Research Journal of Finance and Economics, 16, 35-45. Retrieved from http://www.eurojournals.com/finance.htm

[21] Sohail, N. and Hussain, Z. [2009]. Long-run and short-run relationship between macroeconomic variables and stock prices in Pakistan: The case of Lahore stock exchange. Pakistan Economic and Social Review, 47, 2, 183-198.

[22] Chakravarty, S. [2006]. Stock Market And Macroeconomic Behavior In India. Discussion Paper 106, Institute of Economic Growth, Delhi.

[23] Ahmed, S. [2008]. Aggregate economic variables and stock markets in India. International Research Journal of Finance and Economics, 14, 141-163. Retrieved from http://www.eurojournals.com/finance.htm

[24] Agrawalla, R.K. and Tuteja, S.K. [2008]. Share prices and macroeconomic variables in India: An approach to investigate the relationship between stock markets and economic growth. Journal of Management Research, 8, 3, 136-146.

[25] Singh, D. [2010]. Causal relationship between macroeconomic variables and stock market: A case study for India. Pakistan Journal of Social Sciences [PJSS], 30, 2, 263274 .

[26] Gay, R.D. [2008]. Effect of macroeconomic variables on stock market returns for four emerging economies: Brazil, Russia, India, And China. International Business \& Economics Research Journal, 7, 3, 1-8.

[27] Maysami, R.C. and Koh, T.S. [2000]. A vector error correction model of the Singapore stock market. International Review of Economics and Finance, 9, 1, 79-96. Retrieved from $\mathrm{http}: / /$ www.sciencedirect.com/science/article/pii/S105905609 9000428

[28] Johansen, S. and Juselius, K. [1990]. Maximum likelihood estimation and inference on cointegration - with applications to the demand of money. Oxford Bulletin of Economics and Statistics, 52, 2, 169-210.

[29] Durbin, J. and Watson, G.S. [1951]. Testing for serial correlation in least squares regression II. Biometrika, 38(1-2), 159-177.

[30] Brooks, C. (2008). Introductory Econometrics for Finance $\left(2^{\text {nd }}\right.$ ed.). New York: Cambridge University Press. 